1. Proceedings of the Int. Conf. on Synthetic Metals. Abano Terme, Italy, 1985; Mol. Cryst. Liq. Crvst., 119, № 1-4, 329-412 (1985).

2. Ягубский Э. Б., Щеголев Н. Ф., Лаухин В. Н. и др. Письма в ЖЭТФ, 39, № 1, $12-15$ (1984).

3. Мержанов B. А., Костюченко E. Э., Лаухин В. Н. и др. Письма в ЖЭТФ, 41, № 4, $146-148$ (1985).

4. Каминский В. Ф., Прохорова Т. Г., Шибаева Р. П., Ягубский Э. Б. Письма в ЖЭТФ, 39, № 1, 15-18 (1984).

5. Мержанов В. А., Костюченко E. Э., Фабер О. Е. и др. ЖЭТФ, 89, № 1, $292-297$ (1985).

6. Абрагам А. Ядерный магнетизм. М., ИЛ, 1963.

7. Devreux, F., Nechtschein, M. Lecture Notes in Physics, 95, 145-152 (1979).

Ннститут химической и биологической физики Академии наук Эстонской ССР
Поступила в редакцию $5 / \mathrm{XI} 1985$

EESTI NSV TEADUSTE AKADEEMIA TOIMETISED. FOOSIKA * MATEMAATIKA

ИЗВЕСТИЯ АКАДЕМИИ НАУК ЭСТОНСКОИ ССР. ФИЗИКА - МАТЕМАТИКА PROCEEDINGS OF THE ACADEMY OF SCIENCES OF THE ESTONIAN SSR. PHYSICS * MATHEMATICS

$1986,35,1$

удК 53.082 .56

P. KASK, P. PIKSARV, U. METS, M. POOGA

\title{
ROTATIONAL DIFFUSION OF BOVINE CARBONIC ANHYDRASE $B$ STUDIED BY FLUORESCENCE CORRELATION SPECTROSCOPY
}

\begin{abstract}
P. KASK, P. PIKSARV, $\boldsymbol{O}$. METS, M. POOGA. FLUORESTSENTSKORRELATSIOONSPEKTROSKOOPIA ABIL UURITUD HARJA KARBOANHODRAASI $B$ ROTATOORNE DIFUSIOON

П. КАСК, П. ПИКСАРВ, Ю. МЕТС, М. ПООГА. ВРАЩАТЕЛЬНАЯ ДИФФУЗИЯ КАРБОАНГИДРАЗЫ В КРУПНОГО РОГАТОГО СКОТА, ИССЛЕДОВАННАЯ МЕТОДОМ ФЛУОРЕСЦЕНТНОИ КОРРЕЛЯЦИОННОИ СПЕКТРОСКОПИИ
\end{abstract}

\section{(Presented by E. Lippmaa)}

Fluorescence correlation spectroscopy (FCS) $\left.{ }^{[1}\right]$ is a method for studying the dynamics of molecular number fluctuations under the conditions of a small mean number of fluorescent molecules per sample volume. It has mostly been applied to translational diffusion of labeled molecules in different media: in solutions $\left[{ }^{2,3}\right]$, on membranes $\left[{ }^{4}\right]$, and in isolated cell nuclei $\left.{ }^{5}\right]$. The typical time range of FCS lies between a tenth and hundreds of milliseconds. If photostable labels are used, FCS permits a good signal-to-noise ratio in this time range.

Application of FCS in rotational diffusion studies is also expected by the theory ${ }^{[6]}$. The rotational relaxation time of many important biopolymers lies in the time range of tens of nanoseconds. Recently the extension of FCS into the nanosecond time range was demonstrated, observing the photon antibunching in dye fluorescence $\left.{ }^{[7}\right]$. The present work has been undertaken to clarify the possibilities of the method to be applied in rotational diffusion studies. when

In case of a rigid spherical macromolecule and fast solution flow,

$$
4 D / w^{2} \ll V / w \ll 1 / \tau_{r} \ll 1 / \tau
$$


(where $D$ is the translational diffusion coefficient, $w$ is the radius of the exciting laser beam; $V$ is the solution flow velocity; $\tau_{r}$ is the rotational relaxation time of a rigid spherical molecule; and $\tau$ is the lifetime of the singlet excited state of the label); the formula for the normalized fluorescence intensity autocorrelation function looks as follows -

$$
g(t)=1+N^{-1}\left\{-(1+a) \exp (-t / \tau)+a \exp \left(-t / \tau_{r}\right)+\exp \left[-(V t / \omega)^{2}\right]\right\} .
$$

Here $N$ is the mean number of labeled molecules per sample volume, and $a$ is an amplitude defined by experimental geometries. Eq. (2) is a symbiosis of the formulas derived by $M$. Ehrenberg and R. Rigler ${ }^{6}{ }^{6}$, and D. Magde et al. $\left[{ }^{8}\right]$. The first member in the braces is the photon antibunching term, the second - the rotational diffusion term, and the last one describes the solution flow.

In our experiment the intensity autocorrelation function of fluorescence from a sample of about $150 \mu \mathrm{m}^{3}$ volume is measured. The apparatus is similar to that used in the photon antibunching experiment [ ${ }^{7}$ ]. Some slight changes in microfluorimeter were required. The fast solution flow is created in the sample cell. The solution enters the cuvette through a syringe needle which is strictly aimed at the focus of observation. The input and the output of the cuvette are connected to two vessels at different solution levels. Depending on the level difference, the flow velocity can be settled between 0 and about $200 \mathrm{~mm} / \mathrm{s}$. The flow velocity is estimated by fluorescence correlation experiments in the microsecond time range (see the last member in Eq. (2)), using a 32 -channel clip-correlator $\left[{ }^{9}\right]$. The flow exchanges the bleached molecules for the fresh ones. This process is faster and more complete than exchange by diffusion.

The fluorescence emission is observed, using a water immersion objective with the aperture number 0.9 . The output light passes a polarizer, transmitting only the «parallel» component of emission. The remained parts of the apparatus are described in [7]. The electronic part of the apparatus consists of two photon detectors, a time to amplitude converter and a multichannel pulse amplitude analyser. It records the distribution of the time interval between the two consecutive events of photon detection. The channel width of 0.337 ns was selected and 500 memory channels of the multichannel analyser were used. The time response function of the system has FWHM of $1.2 \mathrm{~ns}$.

For labeling the bovine carbonic anhydrase $B$ (BCA), approximately tenfold molar excess of dry tetramethylrhodamine isothiocyanate (TRITC) powder was added to the $2-5 \mathrm{mg} / \mathrm{ml}$ solution of $\mathrm{BCA}$ in $0.15 \mathrm{M}$ sodium carbonate buffer, $\mathrm{pH} 9.0$, at $4^{\circ} \mathrm{C}$. The mixture was left stirring in the dark at $4^{\circ} \mathrm{C}$. After $12-16$ hours of conjugation the reaction mixture was passed through a Sephadex G-15 column equilibrated with $0.005 \mathrm{M}$ sodium carbonate, $\mathrm{pH} 9.0$. The main fraction containing labeled protein BCA-TRITC was chromatographed on a Sephadex G-75 superfine column equilibrated with $0.025 \mathrm{M}$ tris- $\mathrm{HCl}, \mathrm{pH} 7.0$, and the second coloured fraction was collected. The dye-to-protein ratio was estimated by light absorption measurements to be about 0.4 .

$250 \mathrm{ml}$ of about $4 \times 10^{-10} \mathrm{M}$ solution of BCA-TRITC in $0.025 \mathrm{M}$ tris- $\mathrm{HCl}, \mathrm{pH} 7.0$, was prepared for the fluorescence correlation experiment, an amount which flows through our cuvette in 10 hours if flow velocity of $50 \mathrm{~mm} / \mathrm{s}$ is generated in the sample region. Laser beam power was $24 \mathrm{~mW}$. According to simple calculations the lifetime of the ground state is about $7 \mathrm{~ns}$ in the centre of the focused $24 \mathrm{~mW}$ laser beam and at the most favourable orientation of the label. The average photon counting, rate in both the start and the stop channels was $42,000 \mathrm{~s}^{-1}$. Pure water would give the counting rate as low as $8,000 \mathrm{~s}^{-1}$. 
The fluorescence intensity autocorrelation function was calculated from the measured distribution function of a 10-hour experiment by a procedure described in [ $\left.{ }^{7}\right]$. This function has a minimum around the zero argument, and a slower component of positive amplitude, just as described by the first two terms of Eq. (2).

The values of the parameters of the fit curve are $N=24, a=1.22$, $\tau=1.7 \mathrm{~ns}$ and $\tau_{r}=14.7 \pm 1.5 \mathrm{~ns}$. The estimated value of $\tau_{r}$ for BCATRITC at $22{ }^{\circ} \mathrm{C}$ in $0.025 \mathrm{M}$ tris- $\mathrm{HCl}$ buffer, $\mathrm{pH} 7.0$, corresponds to the rotational diffusion coefficient of $(1.14 \pm 0.11) \times 10^{7} \mathrm{~s}^{-1}$. The apparent $N$ value is well comparable with the number of labeled molecules per sample volume, $N=32$, calculated from the concentration of the label in prepared solution.

The further gain in the $\mathrm{S} / \mathrm{N}$ of the fluorescence correlation experiment, which can be attained by higher efficiences of fluorescence light collection, filtering and photon detection, will certainly increase the possibilities of the FCS as compared to another fluorescence method where the time dependent decay of the fluorescence polarization after pulse excitation is observed. Some principal advantages of the FCS have been discussed by $M$. Ehrenberg and R. Rigler [ $\left.{ }^{6}\right]$.

\section{REFE RE N C E S}

1. Magde, D., Elson, E. L., Webb, W. W. Phys. Rev. Lett., 29, № 11, 705-708 (1972).

2. Magde, D., Elson, E. L., Webb, W. W. Biopolymers, 13, № 1, 29-61 (1974).

3. Rigler, R., Grasselli; P., Ehrenberg, M. Phys. scr., 19, 486-490 (1979).

4. Fahey, P. E., Koppel, D. E., Barak, L. S., Wolf, D. E., Elson, E. L., Webb, W. W. Science, 195, 305-306 (1977).

5. Sorscher, S. M., Bartholomew, J. C., Klein, M. P. Biochim. Biophys. Acta, 610, $28-46$ ((1980).

6. Ehrenberg, M., Rigler, R. Chem. Phys., 4, № 3, 390-401 (1974).

7. Kask, P., Piksarv, P., Mets, O. Eur. Biophys. J., 12, № 3, 163-166 (1985)

8. Magde, D., Webb, W. W., Elson, E. L. Biopolymers, 17, № 3, 361-376 (1978).

9. Sirk, A., Kask, P., Kändler, T., Karu, T., Puskar, J., Lippmaa, E. ENSV TA Toim. Füüs. Matem., 28, № 3, 227-232 (1979).

Academy of Sciences of the Estonian SSR,

Institute of Chemical Physics and Biophysics

Received

Nov. 5,1985

удк $517.94+519.46+539.12$

Групповой анализ некоторых обыкновенных дифференциальных уравнений. Айнсаар $A$., Кийранен К. - Изв. АН ЭстССР. Физика * Математика, 1986, т. 35, № 1, с. $1-8$ (англ.; рез. эст., рус.)

На примере обычных дифференциальных уравнений типа $u_{x x}=a(u)$ рассматриваются следующие вопросы: нахождение групп точечных преобразований, допускающихся этими уравнениями, специализация этих уравнений, нахожденне преобразований между двумя уравнениями и связи между преобразованиями Ли-Беклунда этих уравнений, а также проблема однозначного соответствня между уравнениями и группамн. Бнбл. 14 назв.

\section{УдК 535.345 .673}

Просветление поглощающих пленок. $\overline{|К а р д ~ П .| ~}-$ Изв. АН ЭстССР. Физика * Математика, 1986, т. 35, № 1, с. $9-19$ (рез. эст., нем.)

На основе векторного представлення группы пленок выведены условия, которым должна удовлетворять пленка, просветляющая заданную поглощающую пленку. Получена также общая формула матрицы интерференцин просветленной поглощающей пленки. Библ. 1 назв. 